\title{
Food and Feeding Habits of Atya gabonensis from Lower River Benue in Northern Nigeria
}

\author{
R. A. Obande ${ }^{1 *}$ and K. Kusemiju ${ }^{2}$ \\ ${ }^{1}$ Department of Fisheries, University of Agriculture, Makurdi, Nigeria \\ ${ }^{2}$ Department of Zoology, University of Lagos, Lagos, Nigeria \\ *Conrrespondence author
}

\begin{abstract}
The study investigated the stomach content of Atya gabonensis from lower River Benue in Nigeria from January 1998 to January 2000.The stomach analysis was carried out using frequency of occurrence and numeric methods. It was observed that the organism fed on algae, diatoms, insect parts and detritus, algae and detritus forming the most important food items. Algae constituted $61.9 \%$ of food item by number and $88.5 \%$ by occurrence. Detritus occurred in $79.1 \%$ of stomachs examined. Amongst the algae, Scenedesmus quaricauda was the most preferred, constituting $20.7 \%$ by occurrence and $37.9 \%$ by number, followed by spirogyra which constituted $17.8 \%$ and $23.9 \%$ by occurrence and number, respectively. The least eaten food item was insect parts. A. gabonensis can be said to be an omnivorous detrivore, its preference for food changing with season and size of the prawn with peak in July.
\end{abstract}

\section{Introduction}

Atya gabonensis is a freshwater prawn, which was first reported in Gabon (Powell, 1982). It inhabits clear waters, burrows on root masses, crevices and rocky bottoms. Reed (1967) reported the occurrence of $A$. gabonensis in large Nigerian rivers. It has been found to occur in great abundance in River Benue.

Food studies in fish and shell fishes are carried out to determine the diet of the species and its implication for the management of the fisheries. According to Wootton (1992), food and feeding habits are indispensable part of biological and taxonomic studies because it is an essential function of an organism as growth, development and reproduction are all dependent on energy that enters an organism in the form of food. Food, therefore, is a basic determinant of distribution, abundance and rate of growth of prawns. Prawns are said to be omnivorous, eating all types of food (Adetayo \& Kusemiju, 1994). Their diets also include aquatic insects and larvae, algae, detritus, mollusca and crustaceans (New, 1987; Lee et al., 1980), and they depend heavily on natural foods. Kurian \& Sebastian (1982) also observed that adult prawns fed on plants and animal matter as well as detritus, while New (1990) reported that the stomachs of first year individual prawns contained large proportion of diatoms.

Adetayo \& Kusemiju (1994) also reported that prawns are detritvorous and omnivorous and that filamentous algae and detritus constituted the most important food items occurring in every stomach of Peneaus notialis. Khan et al. (2001) observed that the food of both juvenile and adult penaeids consisted of microalgal cells and organic detritus. Similarly, New (1990) observed that prawns were detrivorous and omnivorous, and that the food item found in the stomach were routinely consumed by young penaeids.

The aim of the study was to investigate the type of food eaten by A. gabonensis. Such studies could be important in the rational management and culture of the commercially important freshwater prawn.

\section{Materials and methods}

A total of 1000 specimens of A. gabonensis were collected from lower River Benue forthnightly from January 1998 to January 2000, with the assistance of fishermen using local traps. The specimens were kept in icechests before being taken to the laboratory to be examined immediately or kept in a deep freezer $\left(0-4{ }^{\circ} \mathrm{C}\right)$ to reduce post humous digestion. The analysis of the stomach content was carried out by both frequency of occurrence and numerical methods as described by Hyslop (1980). Out of the 1000 stomachs examined, 48 (4.8\%) were empty. The food organisms were identified using relevant keys (Yoloye, 1994; Wiafe \& Frid, 2001).

West African Journal of Applied Ecology - Volume 13 
In the frequency of occurrence method, the number of times each food item occurred in the stomach was recorded. The per-centage of the frequency of occurrence was calculated relative to the number of stomachs that contained food items. The merit of this method is that it gives good information on the various types of organisms fed upon, while the demerits are that (i) it does not give information on the quantities or numbers of food items, and (ii) it does not give consideration to the accumulation of food organism which are resistant to digestion. The numerical method involves counting the number of individual food items in each stomach and the total of each food item as the percentage of the total number of all food items eaten by the prawn. The merit of this method is that one can determine the relative significance of the different food items, but its demerit is that the most numerous organisms may not necessarily constitute the most important food item.

Stomach contents of A. gabonensis

\section{Results}

The major food items found in the stomach of A. gabonensis are shown in Table 1. Algae and detritus constituted the most important food items occurring in every stomach examined. Algae formed the major constituents of the stomach constituting about $61.9 \%$ of food items by number and $88.5 \%$ by occurrence. Diatoms formed the second largest constituents of the stomach, accounting for $20.9 \%$ by number and $63.0 \%$ by occurrence, respectively. The third most important food item was insect parts, which constituted $1.9 \%$ by number and $5.0 \%$ by occurrence. The alimentary canals were found to contain food items in association with sand grains, which occurred in $95.2 \%$ of the specimens. They were found to be in association with unidentified masses, which probably were part of the detritus matter or undigested food items.

TABLE 1

Stomach contents of A. gabonensis collected from River Benue

Number $=1000 ;$ No. of empty stomachs $=48 \% ;$ Empty stomach $=4.8 \%$

Food items

Green algae

Akistodesmus falcatus

Spirogyra fragments

Scenedesmus quadricauda

Voltox aureus

Bluegreen algae

Osillatoria corallinae

Anabaena afforus

Closterium ehrenbergi

Chroococus disperses

Pediastrum duplex

Diatoms

Pinnullaria interupta

Tabellaria fenestrate

Melosira varians

Camphylodiscus echenis

Gomphormema sp.

Insect parts

Organic detritus

Sand grains

\begin{tabular}{rc}
\multicolumn{2}{c}{ Numerical method } \\
Number & Percentage \\
& \\
43 & 0.66 \\
1155 & 17.85 \\
1341 & 20.73 \\
528 & 8.16
\end{tabular}

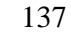

75

418

95

215

642

380

73

104

158

106

950
2.12

1.16

6.46

1.47

3.32

9.92

5.87

1.13

1.61

2.44

1.94

95.2

\begin{tabular}{rc}
\multicolumn{2}{c}{ Occurrence method } \\
Number & Percentage \\
& \\
20 & 1.67 \\
287 & 30.93 \\
299 & 34.4 \\
102 & 8.5 \\
& \\
68 & 5.67 \\
43 & 3.58 \\
15 & 9.58 \\
48 & 4 \\
79 & 6.58 \\
& \\
& \\
268 & 27.84 \\
191 & 20.06 \\
41 & 4.31 \\
55 & 5.78 \\
102 & 10.71 \\
& \\
48 & 5.04 \\
950 & 96.2
\end{tabular}

West African Journal of Applied Ecology - Volume 13 
Amongst the algae, Scenedesmus quaricuada constituted the highest by number (20.7\%) and $34.4 \%$ by occurrence. This was followed by spirogyra fragments, which constituted $17.9 \%$ by number and $30.9 \%$ by occurrence. Closterium_ehrenbergi constituted $6.5 \%$ by number and $9.6 \%$ by occurrence. The least eaten algae species were Chroococcus dispersus, Oscillatoria corallinare, Anabaena affinis, Akistodesmus falcatus and Pediastrum duplex. In the case of diatoms, it was observed that Pinularia interupta was most preferred, accounting for $9.9 \%$ by number and $27.8 \%$ by occurrence. The least eaten diatoms were Gomphornema sp. and Melosira varians. Insect appendages and larvae constituted $1.9 \%$ by number and $5.0 \%$ by occurrence. The unidentified food mass was made up of organic detritus and sand grains, accounting for $95.2 \%$ by occurrence.

Monthly variations in stomach contents of A. gabonensis

The monthly variation in food items of A. gabonensis by number and by occurrence are shown in Table 2. Algae were the most important food item eaten by the species during the period of study. The algae were most preferred in April when it constituted $73.6 \%$ by number and $99.5 \%$ by occurrence. This was followed by diatoms, which were observed throughout the study but mostly in January, June, November and December, when they account for $26.4 \%, 23.4 \%, 24.6 \%$ and $20.7 \%$ by number, and $85.5 \%, 41.2 \%$, $42.0 \%$ and $78.0 \%$ by occurrence, respectively. Insect parts were mostly found in the stomach of the prawns in January, March, June and December, which accounted for $29.9 \%, 29.2 \%, 29.5 \%$ and $26.4 \%$ by number and $80.0 \%, 82.0 \%, 84.6 \%, 74.0 \%$ and $92.0 \%$ by occurrence, respectively.

TABLE 2

Monthly variation in stomach content of Atya gabonensis from lower River Benue (January 1998-December 1998)

\begin{tabular}{|c|c|c|c|c|c|c|c|c|c|c|c|}
\hline \multirow[t]{2}{*}{ Food items } & Analysis & Jan & $\mathrm{Feb}$ & March & April & May & June & July & Aug & Nov & Dec \\
\hline & $\mathrm{N}$ & 43.54 & 64.58 & 55.54 & 73.6 & 57.52 & 57.35 & 67.65 & 66.15 & 51.89 & 52.85 \\
\hline Algae & $\% \mathrm{O}$ & 62.19 & 66.66 & 66 & 99.53 & 88.1 & 92 & 90.2 & 84 & 56 & 62 \\
\hline \multirow{2}{*}{ Diatoms } & $\mathrm{N}$ & 26.4 & 18.5 & 15.23 & 12.77 & 18.77 & 23.44 & 15.99 & 17.33 & 24.64 & 20.66 \\
\hline & $\% \mathrm{O}$ & 85.53 & 77.07 & 56 & 44.43 & 70.7 & 41.2 & 40 & 60 & 42 & 78 \\
\hline Insect parts & $\mathrm{N}$ & 29.97 & 16.88 & 29.23 & 14.09 & 23.56 & 19.07 & 14 & 16.46 & 23.37 & 26.43 \\
\hline$\&$ lavae & $\% \mathrm{O}$ & 80 & 58.33 & 62 & 68.88 & 80.6 & 84.6 & 16.3 & 70 & 74 & 29 \\
\hline \multirow[t]{2}{*}{ Detritus } & $\mathrm{N}$ & 0 & 0 & 0 & 0 & 0 & 0 & 0 & 0 & 0 & 0 \\
\hline & $\% \mathrm{O}$ & 100 & 100 & 100 & 100 & 100 & 100 & 100 & 100 & 100 & 100 \\
\hline \multirow[t]{2}{*}{$\begin{array}{l}\text { No of empty } \\
\text { stomachs }\end{array}$} & & 2 & 0 & 0 & 5 & 4 & 1 & 2 & 1 & 5 & 6 \\
\hline & & \multicolumn{10}{|c|}{$\begin{array}{l}\text { Monthly variation in stomach content of Atya gabonensis from lower RiverBenue } \\
\text { (January 1999-December 1999) }\end{array}$} \\
\hline \multirow[t]{2}{*}{ Algae } & $\mathrm{N}$ & 48.95 & 64.03 & 47.34 & 71.65 & 60.18 & 60.16 & 72.61 & 63.88 & 56.19 & 56.38 \\
\hline & $\% \mathrm{O}$ & 57.11 & 72 & 64.32 & 71.4 & 82.79 & 84.32 & 89.56 & 95.19 & 95.03 & 85.32 \\
\hline \multirow[t]{2}{*}{ Diatoms } & $\mathrm{N}$ & 32.39 & 18.73 & 17.41 & 15.42 & 16.72 & 23.46 & 21.09 & 20.77 & 21.89 & 18.12 \\
\hline & $\% \mathrm{O}$ & 81.94 & 80 & 73.12 & 41.65 & 72.06 & 16.29 & 85.39 & 85.6 & 54.12 & 43.84 \\
\hline \multirow[t]{2}{*}{ Insect parts } & $\mathrm{N}$ & 21.6 & 18.73 & 35.17 & 12.8 & 23.02 & 16.3 & 9.15 & 15.2 & 21.82 & 25.49 \\
\hline & $\% \mathrm{O}$ & 75.5 & 68 & 99.63 & 52.08 & 83.33 & 81.62 & 31.25 & 67.34 & 54.17 & 62.5 \\
\hline \multirow[t]{2}{*}{ Detritous } & $\mathrm{N}$ & 0 & 0 & 0 & 0 & 0 & 0 & 0 & 0 & 0 & 0 \\
\hline & $\% \mathrm{O}$ & 100 & 100 & 100 & 100 & 100 & 100 & 100 & 100 & 100 & 100 \\
\hline $\begin{array}{l}\text { Empty } \\
\text { stomachs }\end{array}$ & & 1 & 0 & 0 & 2 & 2 & 1 & 2 & 1 & 1 & 1 \\
\hline
\end{tabular}

West African Journal of Applied Ecology - Volume 13 
The stomach contents also varied with size. The prawn was grouped into three size groups. The smallest size was $2.0-5.9 \mathrm{~cm}$ total length, medium size $6.0-10.9 \mathrm{~cm}$ total length and largest size was $11.0-14.0 \mathrm{~cm}$. The food items in relation to size are shown in Fig. 1, 2 and 3. There were no differences in food habits of the size groups as algae, insect parts, sand grains and organic detritus were present in their stomachs, irrespective of size. It was, however, observed that algae was the most consumed food item in the smallest prawns $(2.0-5.9 \mathrm{~cm})$, accounting for $86.1 \%$ by number and $90.7 \%$ by occurrence, while it accounted for $60.0 \%$ by number and $61.2 \%$ by occurrence in medium size groups $(6.0-10.9 \mathrm{~cm})$, and $48.5 \%$ by number and $47.0 \%$ by occurrence in large size group $(11.0-14.0 \mathrm{~cm})$. Organic detritus were found in the stomach of all size groups but sand grains were absent in the stomach of small size groups.

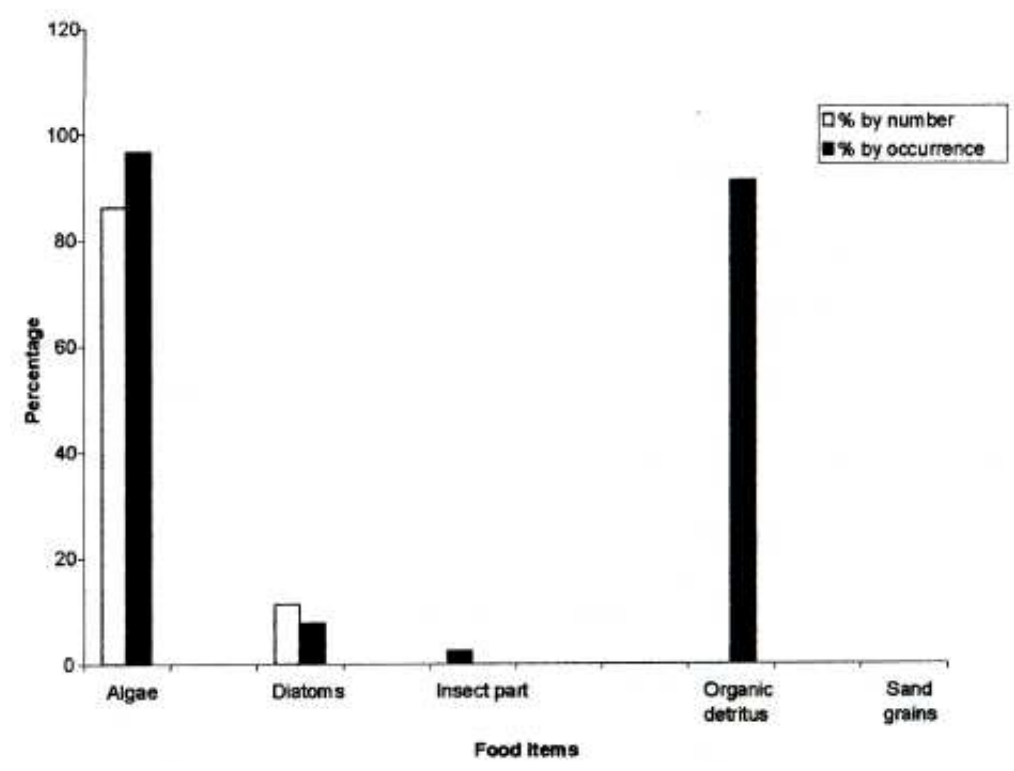

Fig. 1. Major food items in small sized (2.0-5.9) A. gabonensis from lower River Benue 


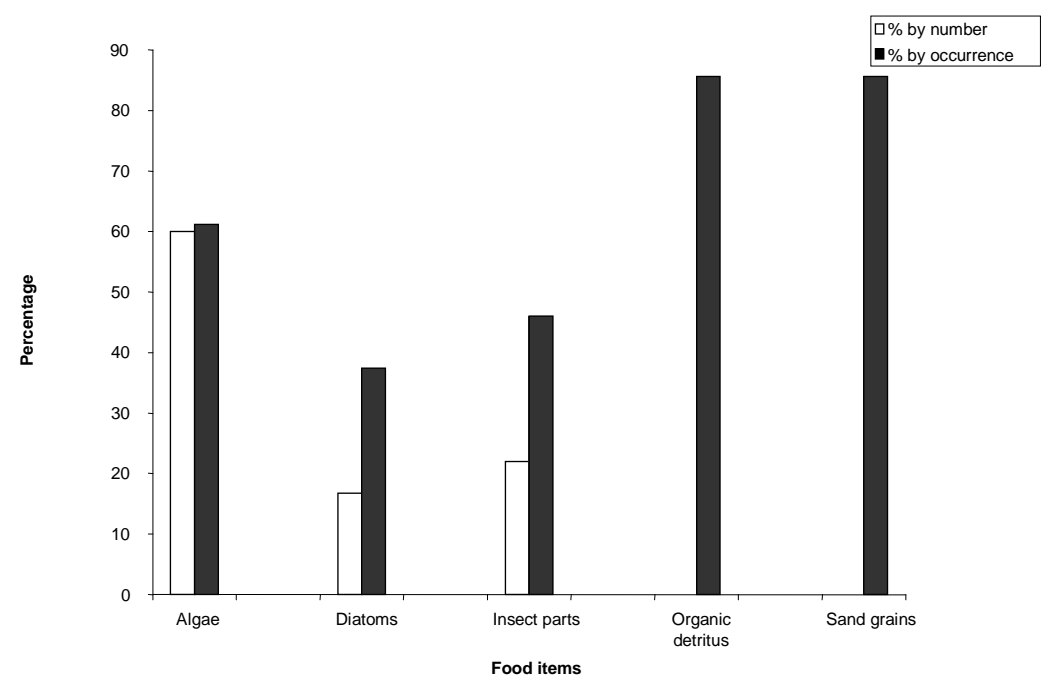

Fig. 2. Major food items in medium sized $(6.0-10.90 \mathrm{~cm})$ A. gabonensis from Lower River Benue

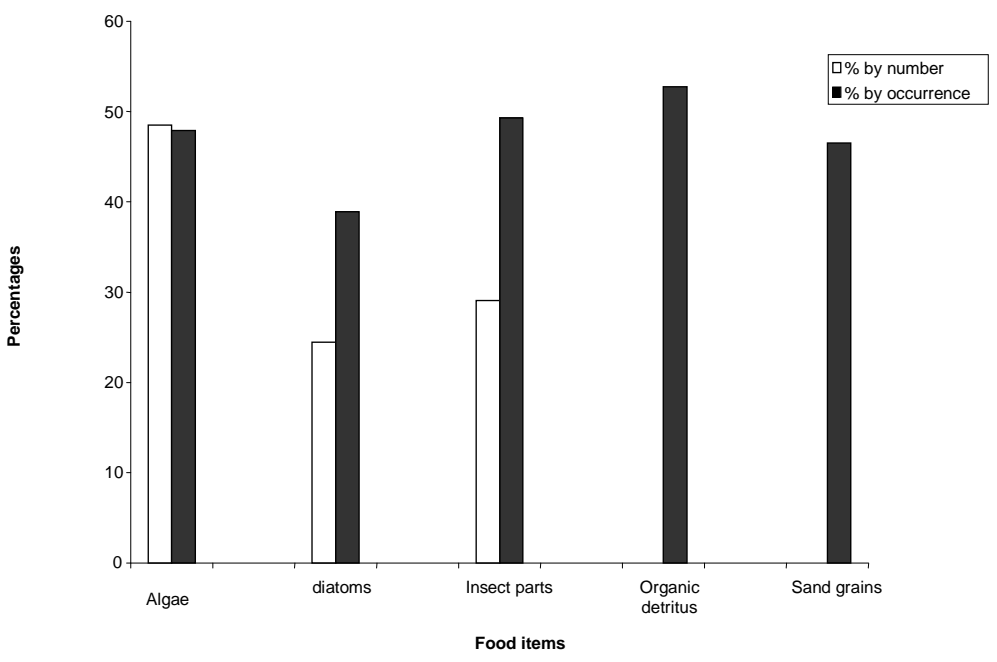

Fig. 3: Major food items in large sized (11.0-14.9cm) A. gabonensis from Lower River Benue

The food items found in the stomach of A. gabonensis were categorized into four groups. These were algae, diatoms, insect parts and organic detritus. The food mostly eaten by the species were algae followed by organic detritus. Among the algae species, Scenedesmus quaricauda was the most preferred food item followed by spirogyra. Diatoms were next to the green algae with Pinnularia interupta being most preferred. The insect parts were most eaten by large sized prawns. A. gabonensis could, therefore, be an omnivorous-detritivore as have been reported by Adetayo \& Kusemiju (1994) for a similar species $P$. notialis, and the presence of insect parts showed that the prawn could be predatory. This observation also agrees with the work of Lee et al. (1980) who reported that the prawns Macobrachium sp. were omnivorous and that their diet included algae, insect parts, plant parts and other animals. New (1990)

West African Journal of Applied Ecology - Volume 13 
observed that prawns, were detrivorous and omnivorous and that the food items found in the stomach of A. gabonensis were routinely consumed by young penaeids.

\section{References}

Adetayo J. A. and Kusemiju K. (1994). Some aspecpts of the biology of the pink shrimp, Penaeus notialis (Perez- Farfante), in the Lagos Lagoon, Nigeria. J. Sci. Res. Dev. 1(1): 80-84.

Hyslop E. J. (1980). Stomach content analysis, A review of methods and their applications. J. Fish. Biol. 17: 411-414.

Kurian C. V. and Sebastian A. (1982). Prawns and prawn fisheries of India. Hindustan Publishing, India. 286 pp.

Khan R. A. Aravindan N. and Kalavat A. (2001). Distribution of two post-larvae species of commercial prawns (Fenneropenaeus indicus and Penaeus monodon) in a coastal tropical estuary. J. Aqua. Sci. 16(2): 99-104.

Lee P. G., Blake N. J. and Rodrick G. E. (1980). Aquaculture analysis of digestive enzymes for the fresh water prawn Macrobrahium rosenbergii. Proc. Wld Maricuture Soc 11: 392-402.

New M. B. (1987). Feed and feeding of fish and prawn. A manual on the preparation and the presentation of compound feeds for prawn and fish in Aquaculture Report No. ADCP/REP/87/26. Aquaculture Development and Co-ordination Programme, FAO, Rome. 275 pp.

New M. B. (1990). Freshwater prawn culture, A review. Aquaculture 88: 99-143.

Powell G. E. (1982). Fresh and brackish water prawns of economic importance in Niger-Delta. In Proceedings of the 2nd Conference of the Fisheries Society of Nigeria, Calabar, Nigeria.

Reed W. (1967). Fisheries of Northern Nigeria. Ministry of Agriculture of Northern Nigeria. 157 pp.

Wiafe G. and Frid C. I. (2001)). Marine Zooplankton of West Africa. Darwin Initiative Rep. 5: 120 pp.

Wootton R. J. (1992). Fish ecology. Blackie and Son Limited. Chapman and Hall, New York. 200 pp.

Yoloye V. I. (1994). Basic Invertebrate Zoology, 3rd edn. Codes and Quantal Publications, Lagos, Nigeria. 320 pp. 